\title{
First report of piscine nodavirus infecting wild winter flounder Pleuronectes americanus in Passamaquoddy Bay, New Brunswick, Canada
}

\author{
Duane E. Barker ${ }^{1, *}$, Ann-Margaret MacKinnon ${ }^{2}$, Linda Boston $^{2}$, \\ Michael D. B. Burt ${ }^{3}$, David K. Cone ${ }^{4}$, David J. Speare ${ }^{5}$, Steve Griffiths ${ }^{6}$, \\ Marcia Cook ${ }^{6}$, Rachael Ritchie ${ }^{6}$, Gilles Olivier ${ }^{2}$ \\ ${ }^{1}$ School of Fisheries, Marine Institute of Memorial University, St. John's, Newfoundland A1C 5R3, Canada \\ ${ }^{2}$ Fish Health Unit, Department of Fisheries \& Oceans, PO Box 5030, Moncton, New Brunswick E1C 9B6, Canada \\ ${ }^{3}$ Huntsman Marine Science Centre, St. Andrews, New Brunswick E5B 2L7, Canada \\ ${ }^{4}$ Department of Biology, Saint Mary's University, Halifax, Nova Scotia B3H 3C3, Canada \\ ${ }^{5}$ Atlantic Veterinary College, Charlottetown, Prince Edward Island C1A 4P3, Canada \\ ${ }^{6}$ Molecular Biology Group, Research Productivity Council, Fredericton, New Brunswick E3B 6Z9, Canada
}

\begin{abstract}
Piscine nodaviruses (Betanodaviridae) are frequently reported from a variety of cultured and wild finfishes. These non-enveloped, single-stranded RNA virions cause viral encephalopathy and retinopathy (VER), also known as viral nervous necrosis (VNN) or fish encephalitis. Recently, nodavirus infections have posed serious problems for larval and juvenile cultured halibut Hippoglossus hippoglossus in Norway and Scotland. To date, no such viruses have been described from any cultured or wild pleuronectid in Atlantic Canada. Obviously, there exists a need to survey wild populations of pleuronectids to assess the risk of potential transfer of nodavirus from wild to caged fishes. This paper presents the results of monthly surveys (April 2000 to March 2001) of viruses from wild winter flounder Pleuronectes americanus collected from Passamaquoddy Bay, New Brunswick, Canada. Tissue samples from wild flounder were screened initially on commercial cell lines (EPC, SSN-1, SHK and CHSE-214) for any evidence of cytopathic effect (CPE). After confirmation of CPE, nodavirus identification was achieved using reverse transcription polymerase chain reaction (RTPCR) analysis. We detected nodavirus from only 1 out of 440 flounder $(0.23 \%)$ examined. This is the first report of piscine nodavirus isolated from wild winter flounder in Atlantic Canada, and although this prevalence may seem low, we discuss the implications of this finding for Canada's emerging halibut aquaculture industry.
\end{abstract}

KEY WORDS: Nodavirus - Betanodavirus · Winter flounder $\cdot$ Pleuronectes americanus $\cdot$ Halibut aquaculture $\cdot$ RT-PCR $\cdot$ Passamaquoddy Bay $\cdot$ New Brunswick $\cdot$ Atlantic Canada

\section{INTRODUCTION}

Viral diseases are among the most problematic pathogens associated with finfish aquaculture. Recently, a piscine nodavirus (Betanodaviridae) responsible for viral encephalopathy and retinopathy (VER),

*E-mail: duane.barker@mi.mun.ca also known as viral nervous necrosis (VNN) or fish encephalitis, has been a serious problem for larval and juvenile halibut Hippoglossus hippoglossus in Norway and Scotland (Grotmol et al. 1995, 1997, Starkey et al. 2000). The causative agent is a non-enveloped, icosahedral, single-stranded RNA virus approximately 25 to $35 \mathrm{~nm}$ in diameter (Munday \& Nakai 1997). This virus invades the brain, resulting in cellular vacuolation and degeneration of the central nervous system, sometimes 
resulting in $100 \%$ mortality among larval and juvenile fishes (Grotmol et al. 1995, 1997, 1999, Munday \& Nakai 1997).

Nodaviruses, traditionally, have been associated with insects and were viewed initially as a new virus of 'warm-water' fishes, first reported in Japanese waters (Yoshikoshi \& Inoue 1990). Since the worldwide expansion of aquaculture and the use of new finfish species, nodavirus isolates have been obtained from over 20 different species among 10 families. New reports of nodavirus include several 'cold-water' species such as the halibut Hippoglossus hippoglossus, the barfin flounder Verasper moseri, the turbot Scophthalmus maximus, and the Pacific cod Gadus macrocephalus (Munday \& Nakai 1997). To date, there are no published records of nodavirus infecting halibut or any other pleuronectid from Atlantic Canada. With the recent emergence of halibut sea-cage farming in Atlantic Canada, it is imperative to assess the risk of

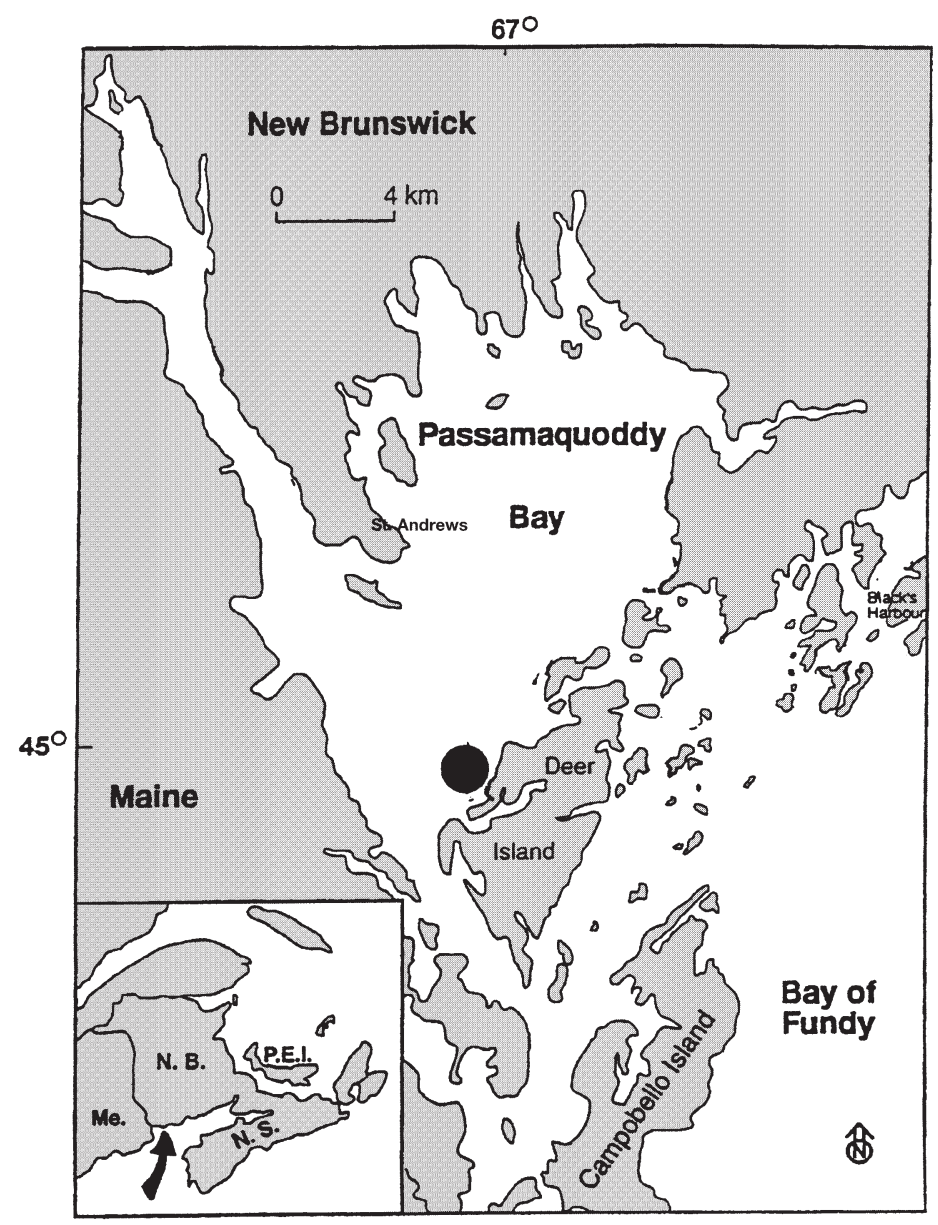

Fig. 1. Map of Passamaquoddy Bay, indicating trawling area (-) used to collect winter flounder Pleuronectes americanus monthly from April 2000 to March 2001. P.E.I.: Prince Edward Island acquiring endemic viruses associated with the local fish fauna, particularly those from other pleuronectids. A 'proactive' approach to address such a need involves initial identification of what viruses are present among local, wild flatfish populations.

As part of an interdisciplinary research group, our prime objectives were to conduct monthly surveys of winter flounder Pleuronectes americanus from Passamaquoddy Bay, New Brunswick, in an attempt to identify all pathogens (viruses and bacteria) and parasites (protozoan and metazoan) present and to determine which of these were pathogenic to halibut. This paper will focus only on the viral surveys. This is the first report of piscine nodavirus isolated from winter flounder in Atlantic Canada.

\section{MATERIALS AND METHODS}

Fish collection. Samples $(\mathrm{n}=40)$ from wild populations of winter flounder Pleuronectes americanus were collected on a monthly basis (April 2000 to March 2001, excluding November 2000). All fish were caught using the Huntsman Marine Science Centre's research vessel 'W.B. Scott', otter trawl towed for $30 \mathrm{~min}$ (depth range 35 to $55 \mathrm{~m}$ ) near Davidson's Head of Deer Island in Passamaquoddy Bay, New Brunswick, Canada $\left(45^{\circ} 00^{\prime} ; 67^{\circ} 00^{\prime} ;\right.$ Fig. 1). All fish were kept alive in a holding tank on the vessel and, later at Huntsman Marine Science Centre, in holding tanks with flowthrough, micropore and sand-filtered, ambient seawater. Within $24 \mathrm{~h}$ of capture, the fish were necropsied and samples were taken for tissue pathology and viral analysis. Several tissue samples (brain, eye, gill, liver, spleen, kidney, intestine and epidermis) from each fish were fixed in $10 \%$ formalin and subsequently stained in hematoxylin and eosin to be examined for signs of gross pathology. In addition, 2 sets of viral pool tissues (liver, spleen, kidney, intestine and gill; eye and posterior brain) were aseptically prepared from each fish and stored (individually) on ice, in sterile plastic bags, for a maximum of $24 \mathrm{~h}$. Initial viral screening was conducted at the Fish Health Unit of the Department of Fisheries and Oceans, Moncton, New Brunswick.

Viral screening. Tissue pools were screened for viral agents using commercial cell lines from the European Collection of Cell Cultures (ECACC). Those chosen for initial screening included the cyprinid cell line epithelioma papillosum cyprini (EPC), the channid cell line striped snakehead (SSN-1), and 2 salmonid cell lines: Atlantic salmon head kidney ( $\mathrm{SHK}_{i}$ Dannevig et al. 1995) and chinook salmon embryo (CHSE-214). The SSN-1 cell lines are preferred for detecting varying genotypes of piscine nodavirus (Iwamoto et al. 1999, Dannevig et al. 2000). 
Tissue pools were homogenized in a dilution of 1:50 w/v in Hanks' balanced salt solution (HBSS) pH 7.6 using a stomacher (Seward Laboratory). The homogenates were centrifuged (Sorvall) at $2500 \times g$ for $15 \mathrm{~min}$ at $4^{\circ} \mathrm{C}$ and the supernatant was aseptically filtered through a $0.45 \mu \mathrm{m}$ pore diameter membrane filter. Using the simultaneously applied cells and test sample method as described in the Fish Health Protection Regulations Manual of Compliance (Anonymous 1984), $0.1 \mathrm{ml}$ of each filtrate prepared from the visceral organs was added in duplicate to 24 well plates (Linbro-ICN) containing EPC, SHK and CHSE-214 cells. Filtrates prepared from eye and brain tissues were inoculated in the same manner onto SSN-1 cells.

Cell lines used for the assays were maintained at 15 to $19^{\circ} \mathrm{C}$ (SHK, CHSE-214 and EPC cells) or $25^{\circ} \mathrm{C}$ (SSN-1 cells) in $25 \mathrm{ml}$ cell culture flasks. The media used consisted of Eagle's minimum essential medium (MEM) at pH 7.2 to 7.6 (CHSE-214 and EPC cells) or Leibovitz L-15 (SHK and SSN-1 cells) containing HBSS, glutamine and $10 \%$ fetal bovine serum (FBS) (CHSE-214 and EPC cells) or $5 \%$ FBS (SSN-1 and SHK cells). In addition, an antibiotic-antimycotic mixture (penicillin, 1000 units $\mathrm{ml}^{-1}$; streptomycin, $1 \mathrm{mg} \mathrm{ml}^{-1}$; and amphotericin $\mathrm{B}, 2.5 \mathrm{~g} \mathrm{ml}^{-1}$ ) was added to the media. Inoculated cell cultures were incubated at $15^{\circ} \mathrm{C}$ (CHSE-214, EPC and SHK cells) or $25^{\circ} \mathrm{C}$ (SSN-1 cells) and examined for a minimum of $28 \mathrm{~d}$ for cytopathic effect (CPE) caused by viral agents. Cell cultures showing CPE were serially diluted 10 -fold and $10^{-1}$ and $10^{-3}$ dilutions were sub-cultured (in a bio-containment hood to prevent contamination) onto the same cell line in which CPE was detected, as previously described. Any sub-culture that showed additional evidence of CPE was sent to the Research Productivity Council in Fredericton, New Brunswick, to be identified using reverse-transcription polymerase chainreaction (RT-PCR) analysis.

Viral identification via RT-PCR. RNA was extracted from the cell culture using the Trizol LS method (Life Technologies). The resulting RNA pellet was suspended in $20 \mu \mathrm{l}$ of DEPC-treated water. RT-PCR was conducted with the ready-to-go system (Amersham Pharmacia Biotech). Briefly, $4 \mu \mathrm{l}$ of re-suspended RNA was reverse transcribed with random hexamers $(2.5 \mu \mathrm{g})$ in a total volume of $40 \mu \mathrm{l}$. The mixture was incubated at $42^{\circ} \mathrm{C}$ for $30 \mathrm{~min}, 95^{\circ} \mathrm{C}$ for $5 \mathrm{~min}$, and left at $4^{\circ} \mathrm{C}$ until primers were added for the PCR reaction. A total volume of $50 \mu \mathrm{l}$ was used in PCR. Primers were suggested by Trine Ranheim from the halibut NNV coat protein gene sequence described by Aspehaug et al. (1999) (NCBI Accession No. AF160473): forward primer, 5' CTGAAGATA CATTCGCTCCAA 3'; reverse primer, 5' TATCCCATAG CCCCCAGTG 3' (Fig. 2). Within the target sequence amplified by Primers F2 and R3 is a region of significant variability among the coat proteins of fish nodaviruses (Nishizawa et al. 1995). Given this variability, such a region

\footnotetext{
1 CGCTTTGCAAGTCAAAATGGTACGCAAAGGTGATAAGAAATTGGCAAAACCCCCGACCACAAAGGCCGCCAATTCTCAAC 81 CACGTCGACGTGCAACACAGCGCCGTCGCAGTGGTAGGGCTGATGCACCCTTAGCTAAGGCATCGACTATCACGGGATTT 161 GGACGTGCGACCAATGATGTCCATATCTCGGGAATGTCACGGATCGCTCAAGCAGTTGTTCCAGCCGGGACAGGAACAGA 241 TGGAAAGATTGTCGTCGATTCCACAATCGTTCCAGAACTCCTGCCACGGCTTGGACACGCTGCTCGAATCTTCCAGCGAT 321 ACGCTGTTGAAACACTGGAGTTCGAAATTCAGCCAATGTGCCCCGCAAACACGGGCGGTGGTTACGTTGCTGGCTTCCTG 401 CCTGATCCAACTGACAACGACCACACCTTCGATGCGCTCCAAGCAACTCGTGGTGCAGTCGTCGCCAAATGGTGGGAAAG 481 TCGAACAGTCCGGCCCCAGTATACTCGAACGCTTCTCTGGACCTCAACCGGGAAGGAGCAGCGATTGACATCACCTGGCC F2 Primer Region

561 GGCTGGTACTCCTGTGTGTTGGCAGCAACACTGATGTTGTCAACGTGTCAGTCATGTGTCGCTGGAGCGTTCGCCTTAGT Forward Primer Region

641 GTCCCGTCCCTTGAGACACCTGAGGACACCACCGCTCCAATTACTACCCAGGCGCCACTCCACAACGATTCCATTAACAA 721 CGGTTACACTGGATTTCGTTCCATTCTCTTGGGCTCGACCCAACTCGACCTCGCTCCTGCAAACGCTGTCTTTGTCACTG 801 ACAAACCGTTGCCCATTGATTACAATCTTGGAGTGGGCGACGTCGACCGGGCCGTGTACTGGCACCTGCAGAAGAAAGCT Reverse Primer Region

881 GGAGACACTCAGGTACCTGCTGGGTACTTTGACTGGGGACTGTGGGATGACTTTAACAAGACATTCACAGTTGGGGCGCC R3 Primer Region

961 CTACTACTCCGACCAGCAACCACGGCAAATCTTGCTGCCGGCTGGCACGCTCTTCACCCGTGTTGACTCGGAAAACTAAC 1041 CGGGTCATCCGGATCCCTAGTGCGTATCGTGGATGACCAATTCGAGAAATTGATTACGGCACTAACCACTATCAAAATTG 1121 AAATTGACAACAACAAGAGCGAAATTGAAGCTATCGCTAACAAATTAAACGACAAAGCACCCAAGGAGGGCTCGATTGCT 1201 ATTGTTGGTACCATTGACGGCGTACCTGGAACAGTTGACGGCGCTTACCTCGCCGAACCTGTCTAGCGTGCTTGATACGG 1281 TGCCAGCTTCACCAGTCTTGTCCAACGCCGAGGATTTCCCTCTTTGGGCTTGTTGGGTTACCGTTAGCTCCGCGCAGTGA 1361 GCACCACCGCCATGTGGTTAAATGGCCGCTGATCGCCACGTTACTCGGCG
}

Fig. 2. Primer annealing regions within the coat protein sequence of nervous necrosis virus. The sequence for striped jack nervous necrosis virus (SJNNV) is shown (Accession No. D30814). The nucleotide sequence depicted here for the forward and reverse primer regions do not match $100 \%$ with the forward and reverse primer sequences since these primers were designed from halibut protein sequences, which varies somewhat from the striped jack sequence. The region actually compared in this paper for the various isolates is in bold-face. The SJNNV sequence contains 6 more nucleotides (Positions 713 to 718: underlined) in this region than the isolates used in this study 
Winter Flounder

Cod (\#8)

Haddock(Shelburne)

Halibut(AF160473)

Barfin flounder(AB046377)

D. labrax (U39876)

Winter Flounder

Cod (\#8)

Haddock(Shelburne)

Halibut(AF160473)

Barfin flounder(AB046377)

D. labrax (U39876)

Winter Flounder

Cod (\#8)

Haddock(Shelburne)

Halibut (AF160473)

Barfin flounder(AB046377)

D. labrax (U39876)

Winter Flounder

Cod (\#8)

Haddock(Shelburne)

Halibut (AF160473)

Barfin flounder(AB046377)

D. labrax (U39876)

Winter Flounder

Cod (\#8)

Haddock(Shelburne)

Halibut (AF160473)

Barfin flounder (AB046377)

D. labrax (U39876)

$\# 1$
$\# 1$
$\# 1$
$\# 1$
$\# 1$
$\# 1$
$\# 1$
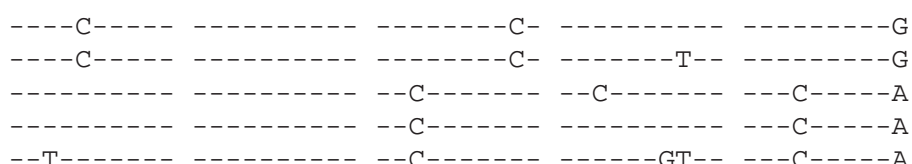

- - $-\mathrm{C}-------------\mathrm{GT}-----\mathrm{C}-----\mathrm{A}$

$-\mathrm{A}-\mathrm{A}---\mathrm{T}--\mathrm{C}-----------------$ - $\mathrm{CA}-\mathrm{ATCT}--\mathrm{C}--------\mathrm{C}$

$\ldots \ldots \ldots \ldots \ldots \ldots \ldots \ldots \ldots \ldots \ldots \ldots \ldots \ldots \ldots \ldots \ldots \ldots \ldots \ldots \ldots \ldots$

\#1 CCCTGGGACC ACTCTACAAC GATtCCCTTG CAGCCAACGA TTtTAAATCR

\# 51

\#51

$\# 51$

\#51

$\# 51$

\#51

\#51

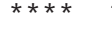

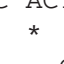

(

*

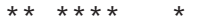

$--\mathrm{G}----\mathrm{T}--\mathrm{A}--\mathrm{C}-$

$-\mathrm{A}--\mathrm{T}-----------\mathrm{C}-----\mathrm{T}-----------\mathrm{T}--\mathrm{C}-$

$-\mathrm{A}--\mathrm{T}-----------\mathrm{C}-----\mathrm{T}-----------\mathrm{T}----$

-

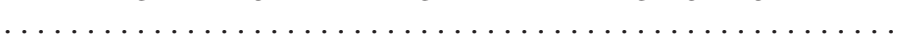

ATCCTCCTTG GCTCTACYCA GCTYGACATC GCCCCYGAAg GAgCCGTCTA

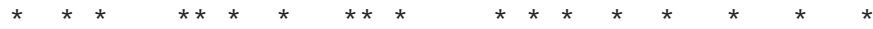

\#101 -A-------C -------- T- ----C--T-- ---------- ----------

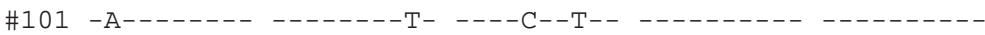

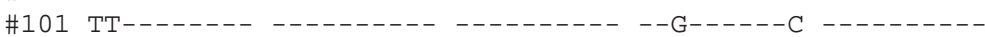

\#101 TT-------- ---------- ---------- --G------C ----------

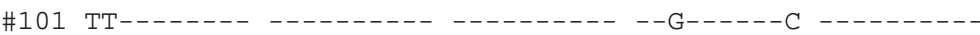

\#101 -CAGA-G--C --C------- -------T-- ---G------ --C--A----

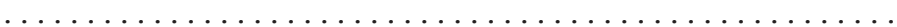

\#101 CWCAttagat CGgCcGctgt CCAttgacta CAAtCtggGa ACtgGtgatg

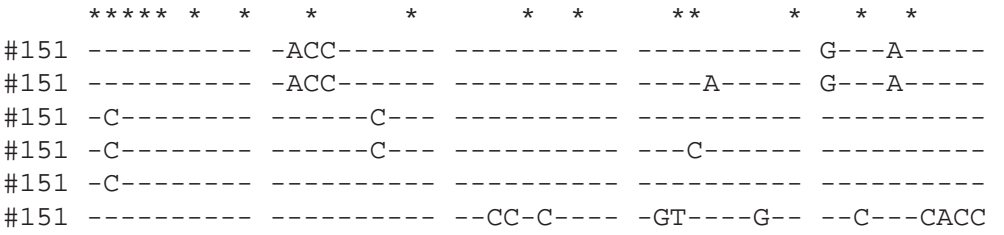

H151-------- --------- --CC-C---- -GT----G-- --C---CACC

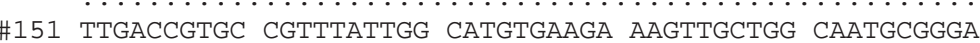
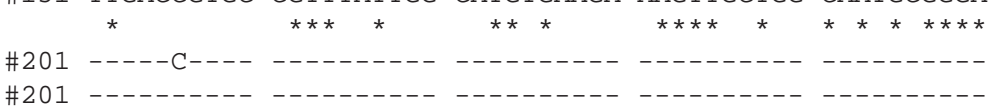

\#201 -

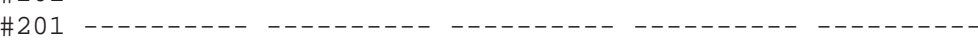

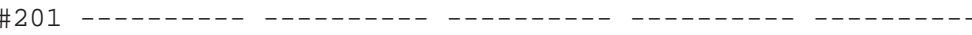

\#201 ------G---- ----------- ----------- ----------- ----------

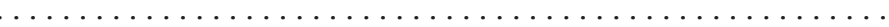

\#201 ACACCTGC

Fig. 3. Summary of nucleotide homologies for nodavirus isolates from winter flounder Pleuronectes americanus, cod Gadus morhua, haddock Melanogrammus alegfinus, halibut Hippoglossus hippoglossus; Accession No. AF160473, barfin flounder Verasper moseri; Accession No. AB046377 and sea bass Dicentrarchus labrax; Accession No. U39876

is preferable for distinguishing isolates genetically. Final concentrations of primers and $\mathrm{MgCl}_{2}$ were $0.8 \mu \mathrm{M}$ and $2 \mathrm{mM}$ respectively. Amplification conditions consisted of 35 cycles of $94^{\circ} \mathrm{C}$ for $45 \mathrm{~s}, 55^{\circ} \mathrm{C}$ for 45 $\mathrm{s}$ and $72^{\circ} \mathrm{C}$ for $45 \mathrm{~s}$ followed by a $7 \mathrm{~min}$ extension period at $72^{\circ} \mathrm{C}$.

Positive controls consisted of nodavirus isolated from cod Gadus morhua (Johnson et al. 2002) and from wild haddock Melanogrammus alegfinus (Mackinnon et al. unpubl. data). All amplifications were conducted using a GeneAmp 9600 (PE Applied Biosystems). RT-PCR products were mixed with non- denaturing loading buffer and visualized by running $5 \mu \mathrm{l}$ on $11 \%$ acrylamide TBE mini gels (mini-Protean II, BioRad, Hercules, CA) and staining with ethidium bromide. In addition, the isolate from winter flounder was compared to nodavirus isolates from barfin flounder (Verasper moseri; Accession No. AB046377) and sea bass (Dicentrarchus labrax; Accession No. U39876).

The 264 bp RT-PCR product was gel-purified by running $40 \mu \mathrm{l}$ on a $1.5 \%$ agarose gel (TBE buffer) at $100 \mathrm{~V}$ for $75 \mathrm{~min}$, excising the $264 \mathrm{bp}$ band and extracting the DNA using the QIAquick gel extraction kit (Qiagen). 
The purified amplification product was sequenced in both directions using the previously described PCR primers. The sequencing reaction $(20 \mu \mathrm{l}$ in total) consisted of $45 \mathrm{ng}$ of DNA template, $3.2 \mathrm{pmol}$ of primer, and $8 \mu \mathrm{l}$ of BigDye Terminator Mix (PE Applied Biosystems) mixed 1:1 with half BD (BioCan Scientific). The cycle sequencing conditions consisted of 25 cycles of $96^{\circ} \mathrm{C}$ for $10 \mathrm{~s}, 50^{\circ} \mathrm{C}$ for $5 \mathrm{~s}$, and $60^{\circ} \mathrm{C}$ for $4 \mathrm{~min}$. The cycle sequence reaction products were purified using Centriflex Gel Filtration Cartridges (BioCan Scientific) and run on an ABI 310 Genetic Analyzer (PE Applied Biosystems). Sequence data was analyzed using SEQUENCHER software (Gene Codes). Phylogenetic associations of the fragments were determined using the BLAST search algorithm (Altschul et al. 1990) of GenBank (National Centre for Biotechnology Information).

\section{RESULTS}

\section{Screening}

During the October 2000 survey, nodavirus was isolated from 1 adult female winter flounder (length = $21 \mathrm{~cm}$, weight $=97.9 \mathrm{~g}$ ) caught in a trawl set at $43 \mathrm{~m}$. Interestingly, there were no obvious clinical symptoms of VNN in the fish (e.g. aberrant swimming, pigment changes, lesions, ulcers) and histological examination of brain and eye tissues showed no signs of tissue vacuolation or any other gross lesions. During screening, complete destruction of the cell monolayer was noted in duplicate wells of SSN-1 cells (containing eye and brain tissue pools) between Days 7 and 14. Both sub-cultured dilutions of the cell lysate from 1 initial screening-well showing CPE completely destroyed the monolayer of a second group of SSN-1 cells between Days 6 and 10 . There was no evidence of CPE using EPC, CHSE-214 and SHK cell lines. Only 1 wild winter flounder out of $440(0.23 \%)$ tested positive for nodavirus.

\section{RT-PCR}

The primers designed originally for the capsid protein of halibut were successful in the amplification of products of the expected size (260 bp approx.) from both the cod nodavirus isolate, used as the positive control, and the cell culture originating from winter flounder suspected of having nodavirus. BLAST analysis of the nucleotide sequence of the RT-PCR product (not including primer sequence regions) revealed highest homology (85\%) with halibut nervous necrosis virus (NNV; Accession No. AF160473; Fig. 3). In addition, the isolate from winter flounder also revealed $84 \%$ homology to barfin flounder NNV (Accession No. AB046377) and 72\% homology to sea bass, Dicentrarchus labrax, encephalitis (Accession No. U39876) coat proteins (Fig. 3). For locally identified isolates from 2 cod samples (Nos. 7 and 8; Johnson et al. 2002) and a haddock, Melanogrammus alegfinus, sample (Mackinnon et al. unpubl. data), nucleotide homologies were 98, 98, and $85 \%$ respectively. Levels of 91, 89, 75, 100, 100, and $89 \%$ homology existed between the amino acid sequences of the winter flounder isolate and the isolates from halibut, barfin flounder, sea bass, Cod No. 7, Cod No. 8, and haddock respectively (Fig. 4).

Winter flounder
Cod \#8
Haddock(Shelburne)
Halibut(AF160473)
Barfin flounder(AB046377)
D. labrax (U39876)
Winter Flounder
Cod \#8
Haddock(Shelburne)
Halibut(AF160473)
Barfin flounder(ABO46377)
D. labrax (U39876)
Winter Flounder
Cod \#8
Haddock(Shelburne)
Halibut(AF160473)
Barfin flounder(ABO46377)
D. labrax (U39876)

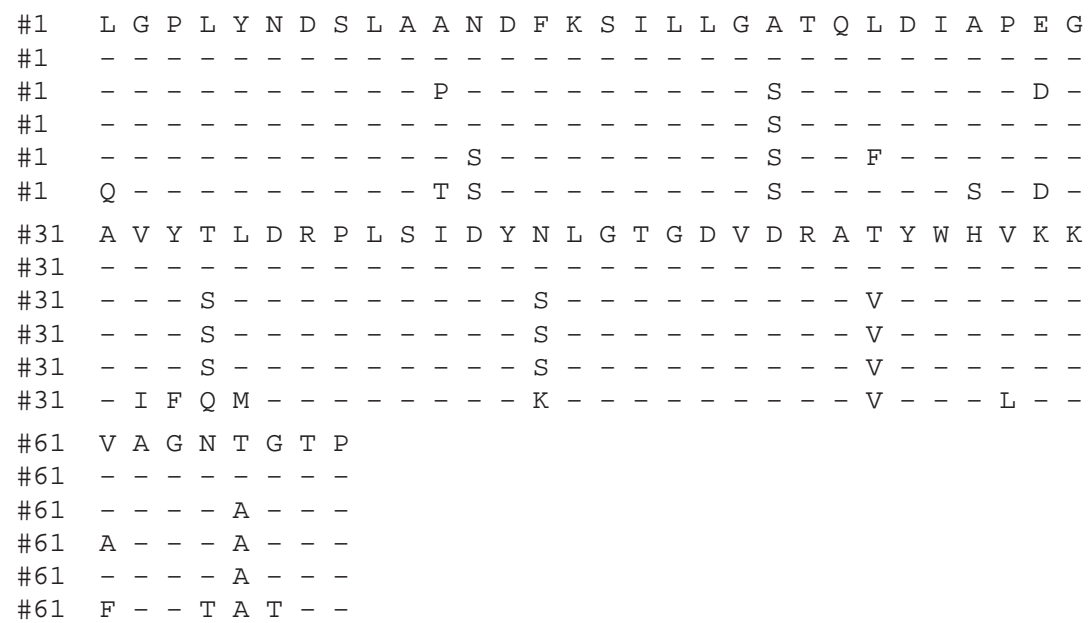

Fig. 4. Summary of amino acid homologies for nodavirus isolates from winter flounder Pleuronectes americanus, cod Gadus morhua, haddock Melanogrammus alegfinus, halibut Hippoglossus hippoglossus; Accession No. AF160473, barfin flounder Verasper moseri; Accession No. AB046377 and sea bass Dicentrarchus labrax; Accession No. U39876 


\section{DISCUSSION}

The lack of any clinical symptoms and obvious pathology is typical of viral infections reported from wild fishes. Most infections are presumably latent and pathology does not manifest itself until the fishes are stressed (e.g. held in captivity or exposed to increased temperatures). Fishes will quickly die (or be predated) when suffering from acute infections; thus it is difficult to find such infections among a wild population. Curiously, both nucleotide and amino acid sequence of the current isolate from winter flounder were more similar to those identified in local cod than to those from other pleuronectids (Atlantic halibut, barfin flounder). This implies that there are regional strains of nodavirus indigenous to Atlantic Canada and that this strain described from winter flounder can be easily passed to cod (and vice versa).

The majority of reports of nodavirus (especially pertaining to pathogenic infections) are from larval and juvenile fishes. However, Aspehaug et al. (1999) were the first to detect it among captive adult halibut (mean length $=71.5 \mathrm{~cm}$, mean weight $=5.4 \mathrm{~kg}$ ) with $9 \%$ of the fish exhibiting clinical symptoms of VNN. Similarly, others have reported nodavirus from adult fishes (e.g. grouper Epinephelus septemfasciatus (Fukuda et al. 1996); striped jack Pseudocaranx dentex (Arimoto et al. 1992, Mushiake et al. 1994) and sea bass Dicentrarchus labrax (Le Breton et al. 1997). The results of the present study add further evidence that adult fishes are also at risk.

Another component of our pleuronectid epidemiological survey (not presented here) focused on using the parasite fauna of our sampled fish as indicators of recent prior residency in shallow (intertidal) or deep (subtidal) water. The nodavirus-infected winter flounder had several metazoan parasites (e.g. many digenean metacercariae of Cryptocotyle lingua, and adult nematodes, Ascarophis arctica) that are acquired in the shallow intertidal zone, indicating that fish previously must have lived there. Any period of residency in shallow water would pose a risk of transfer from wild fish to cultured fish in sea cages. In fact, our sampling area was located approximately $0.5 \mathrm{~km}$ from a commercial salmon sea cage. Interestingly, the only other virus detected in our surveys was IPNV (infectious pancreatic necrosis virus) from 2 of 440 winter flounder $(0.45 \%$; Barker et al. unpubl. data). Again, these were from winter flounder that, based on their intestinal parasites, had recently lived in the shallow intertidal zone.

Our observed nodavirus prevalence of $0.23 \%$ may not appear high, and we may have significantly underestimated the actual prevalence. During initial viral screening, SSN-1 cell lines were incubated at $25^{\circ} \mathrm{C}$; however, Iwamoto et al. (1999) recommend using $20^{\circ} \mathrm{C}$, and reported no growth at $25^{\circ} \mathrm{C}$ and higher for barfin flounder nervous necrosis virus (BFNNV). Our isolate was only $84 \%$ similar (protein coat sequence) and $89 \%$ similar (amino acid sequence) to that of BFNNV, but would still be considered a member of that psychophilic group of nodaviruses. Combining this factor with the possibility of low viral concentrations (below CPE detection) among asymptomatic wild fish, would certainly contribute to many negative test results and a low sample prevalence. In addition, many wild fish may have already succumbed to an acute infection and could not be sampled. Furthermore, our monthly samples were from a defined area within Passamaquoddy Bay $\left(45^{\circ} 00^{\prime} ; 67^{\circ} 00^{\prime}\right.$; approx. $\left.2 \mathrm{~km}^{2}\right)$, it is possible that there may be localized patches of piscine NNV within the bay that were not sampled. Given such factors, we were fortunate to have detected any NNV in our samples.

Preliminary results from mark-recapture studies estimate a winter flounder population of over 100000 individuals within $2 \mathrm{~km}^{2}$ of our sampling area (Barker et al. unpubl. data). Based on our sample prevalence, this implies there are over 230 infected winter flounder within our sampling area and perhaps an alarming number in Passamaquoddy Bay. According to Frerichs et al. (2000), sea bass nodavirus was quite viable after 6 mo in seawater (37 and $20 \%$ ) at $15^{\circ} \mathrm{C}$. The mean monthly temperatures of seawater within Passamaquoddy Bay rarely get above $15^{\circ} \mathrm{C}$ (Robinson et al. 1996). It is conceivable that this virus may be stable for almost a year in our sampling area. Moreover, several studies have successfully infected fishes with nodavirus via water-borne challenges (Glazebrook et al. 1990, Mori et al. 1991, Arimoto et al. 1993, Tanaka et al. 1998, Grotmol et al. 1999). Therefore, it is theoretically possible that nodavirus could be transferred between wild winter flounder and sea-caged halibut or cod.

Finally, the results of the present study are also significant in that the distribution range of piscine nodavirus has once again expanded. Over the past $10 \mathrm{yr}$, with more sampling effort, reports of VNNcausing nodaviruses have come from Japan, Australia, Asia, Europe, Norway, Eastern Pacific and now Atlantic Canada. Consequently, these results will further complicate any fish transfer nationally and internationally. It is likely that this pathogen is much more ubiquitous (with several regional strains) and endemic than we previously believed, and thus warrants further research.

Acknowledgements. This project was funded by an NSERC strategic grant (no. 224165-1999) awarded to D.K.C., M.D.B.B., R. R. Cusack and D.J.S. We thank the following for 
their technical assistance with sample collection and fish necropsy: A. J. Mullen, A. Clarke, V. Barteaux, S. Mipangho, J. Wade, C. Waters, L. Lush and C. Imbeault. In addition, we appreciate the use of the facilities at the Huntsman Marine Science Centre and the cooperation of their maintenance staff (F. Purton, D. Parker and S. Foster) and research vessel crew (E. Carter, M. Burgess, J. Eldrige and T. Hurley).

\section{LITERATURE CITED}

Altschul SF, Madden TL, Schaffer AA, Zhang J, Zhang Z, Miller W, Lipman DJ (1990) Gapped BLAST and PSIBLAST: a new generation of protein database search programs. Nucleic Acids Res 25:3389-3402

Anonymous (1984) Department of fisheries and oceans fish health protection regulations: manual of compliance. Fish Mar Serv Misc Spec Publ 31:1-32

Arimoto M, Mushiake K, Mizuta Y, Nakai T, Muroga K, Furusawa I (1992) Detection of striped jack nervous necrosis virus (SJNNV) by enzyme-linked immunosorbent assay (ELISA). Fish Pathol 27:191-195

Arimoto M, Mori K, Nakai T, Muroga K, Furusawa I (1993) Pathogenicity of the causative agent of viral nervous necrosis disease in striped jack, Pseudocaranx dentex. J Fish Dis 16:461-469

Aspehaug V, Devold M, Nylund A (1999) The phylogenetic relationship of nervous necrosis virus from halibut (Hippoglossus hippoglossus). Bull Euro Assoc Fish Pathol 19: 196-202

Dannevig BH, Falk K, Namork E (1995) Isolation of the causal virus of infectious salmon anaemia (ISA) in a long-term cell line from Atlantic salmon head kidney. J Gen Virol 76: 1353-1359

Dannevig BH, Nilsen R, Modahl I, Jankowska M, Taksdal T, Press CM (2000) Isolation in cell culture of nodavirus from farmed Atlantic halibut Hippoglossus hippoglossus in Norway. Dis Aquat Org 43:183-9

Frerichs GN, Tweedie A, Starkey WG, Richards RH (2000) Temperature, $\mathrm{pH}$ and electrolyte sensitivity, and heat, UV and disinfectant inactivation of sea bass (Dicentrarchus labrax) neuropathy nodavirus. Aquaculture 185:13-24

Fukuda Y, Nguyen HD, Furuhasi M, Nakai T (1996) Mass mortality of cultured sevenband grouper, Epinephelus septemfasciatus, associated with viral nervous necrosis. Fish Pathol 31:165-170

Glazebrook JS, Heasman MP, Beer SW (1990) Picorna-like viral particles associated with mass mortalities in larval barramundi, Lates calcarifer Bloch. J Fish Dis 13:245-249

Grotmol S, Totland GK, Kvellestad A, Fjell K, Olsen AB (1995) Mass mortality of larval and juvenile hatchery-reared halibut (Hippoglossus hippoglossus L.) associated with the presence of virus-like particles in vacuolated lesions in the

Editorial responsibility: Jo-Ann Leong,

Corvallis, Oregon, USA central nervous system and retina. Bull Eur Assoc Fish Pathol 15:176-180

Grotmol S, Totland GK, Thorud K, Hjeltnes BK (1997) Vacuolating encephalopathy and retinopathy associated with a nodavirus-like agent: a probable cause of mass mortality of cultured larval and juvenile Atlantic halibut Hippoglossus hippoglossus. Dis Aquat Org 29:85-97

Grotmol S, Bergh Ø, Totland GK (1999) Transmission of viral encephalopathy and retinopathy (VER) to yolk-sac larvae of the Atlantic halibut Hippoglossus hippoglossus: occurrence of nodavirus in various organs and a possible route of infection. Dis Aquat Org 36:95-106

Iwamoto T, Mori K, Arimoto M, Nakai T (1999) High permissivity of the fish cell line SSN-1 for piscine nodaviruses. Dis Aquat Org 39:37-47

Johnson SC, Sperker SA, Leggiadro CT, Groman DB, Griffiths SG, Ritchie RJ, Cook MD, Cusack RR (2002) Identification and characterization of a piscine neuropathy and nodavirus from juvenile Atlantic cod (Gadus morhua). $\mathrm{J}$ Aquat Anim Health (in press)

Le Breton A, Grisez L, Sweetman J, Ollevier F (1997) Viral nervous necrosis (VNN) associated with mass mortalities in caged-reared sea bass, Dicentrarchus labrax (L.). J Fish Dis 20:145-151

Mori K, Nakai T, Nagahara M, Muroga K, Mekuchi T, Kanno $\mathrm{T}$ (1991) A viral disease in hatchery-reared larvae and juveniles of redspotted grouper. Fish Pathol 26:209-210

Munday BL, Nakai T (1997) Special topic review: nodaviruses as pathogens in larval and juvenile marine finfish. World $\mathrm{J}$ Microbiol Biotechnol 13:375-381

Mushiake K, Nishizawa T, Nakai T, Furusawa I, Muroga K (1994) Control of VNN in striped jack, selection of spawners based on the detection of SJNNV gene by polymerase chain reaction (PCR). Fish Pathol 29:177-182

Nishizawa T, Mori K, Furuhashi M, Nakai T, Furusawa I, Muroga K (1995) Comparison of the coat protein genes of five fish nodaviruses, the causative agents of viral nervous necrosis in marine fish. J Gen Virol 76:1563-1569

Robinson SMC, Martin JD, Page FH, Losier R (1996) Temperature and salinity characteristics of Passamaquoddy Bay and approaches between 1990 and 1995. Can Tech Rep Fish Aquat Sci 2139:1-56

Starkey WG, Ireland JH, Muir KF, Shinn AP, Richards RH, Ferguson HW (2000) Isolation of nodavirus from Scottish farmed halibut, Hippoglossus hippoglossus (L.). J Fish Dis 23:419-422

Tanaka S, Aoki H, Nakai T (1998) Pathogenicity of the nodavirus detected from diseased sevenband grouper Epinephelus septemfasciatus. Fish Pathol 33:31-36

Yoshikoshi K, Inoue K (1990) Viral nervous necrosis in hatchery-reared larvae and juveniles of Japanese parrot fish, Oplegnathus fasciatus (Temminck \& Schlegel). J Fish Dis 13:69-77

Submitted: June 6, 2001; Accepted: November 9, 2001

Proofs received from author(s): March 28, 2002 